\title{
Glutamatergic gene expression is specifically reduced in thalamocortical projecting relay neurons in schizophrenia
}

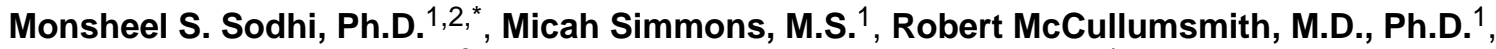 \\ Vahram Haroutunian, Ph.D. ${ }^{3}$, and James H. Meador-Woodruff, M.D. ${ }^{1}$ \\ ${ }^{1}$ Dept. Psychiatry and Behavioral Neurobiology, UAB, $17207^{\text {th }}$ Avenue Sth. Birmingham, \\ Alabama 35294-0019, USA \\ ${ }^{2}$ Dept. Pharmacy Practice and Center for Pharmaceutical Biotechnology, College of Pharmacy, \\ 900 S Ashland Ave, Chicago, Illinois 60607-4067, USA \\ ${ }^{3}$ Dept. Psychiatry, The Mount Sinai School of Medicine, One Gustave L. Levy Place, New York, \\ New York 10029-6574, USA
}

\begin{abstract}
Background-Impairment of glutamate neurons which relay sensory and cognitive information from the medial dorsal thalamus to the dorsolateral prefrontal cortex and other cortical regions may contribute to the pathophysiology of schizophrenia. In this study we have assessed the cellspecific expression of glutamatergic transcripts in the medial dorsal thalamus.
\end{abstract}

Methods and Materials-We used laser-capture microdissection to harvest two populations of medial dorsal thalamic cells, one enriched with glutamatergic relay neurons, and the other with GABAergic neurons and astroglia, from postmortem brains of subjects with schizophrenia $(n=14)$ and a comparison group $(n=20)$. Quantitative polymerase chain reaction (QPCR) of extracted RNA was used to assay gene expression in different cell populations.

Results-The transcripts encoding the ionotropic glutamate receptor subunits NR2D, GluR3, GluR6, GluR7, and the intracellular proteins GRIP1 and SynGAP1 were significantly decreased in relay neurons but not in the mixed glial and interneuron population in schizophrenia.

Discussion-Our data suggest that reduced ionotropic glutamatergic expression occurs selectively in neurons giving rise to the cortical projections of the medial dorsal thalamus in schizophrenia, rather than in thalamic cells which function locally. Our findings indicate that glutamatergic innervation is dysfunctional in the circuitry between the medial dorsal thalamus and cortex.

Keywords

Postmortem gene expression; receptor; laser-capture microdissection; medial dorsal thalamus

(C) 2011 Society of Biological Psychiatry. Published by Elsevier Inc. All rights reserved.

*Correspondence should be addressed to: Monsheel Sodhi Ph.D., 900 S. Ashland Ave. Chicago IL 60607-4067, USA, Tel: +1-312-355-5949, Fax: +1-312-413-9303, mssodhi@uic.edu.

Financial disclosures

The authors reported no biomedical financial interests or potential conflicts of interest.

Publisher's Disclaimer: This is a PDF file of an unedited manuscript that has been accepted for publication. As a service to our customers we are providing this early version of the manuscript. The manuscript will undergo copyediting, typesetting, and review of the resulting proof before it is published in its final citable form. Please note that during the production process errors may be discovered which could affect the content, and all legal disclaimers that apply to the journal pertain. 


\section{Introduction}

Schizophrenia is a debilitating psychiatric disorder which occurs in approximately $1 \%$ of the population worldwide. Its etiology is not known, but with accumulating data, the glutamate hypothesis of schizophrenia has gained credibility (1-5). This hypothesis proposes that dysregulation within the glutamate neurotransmitter system contributes to the pathophysiology of schizophrenia, and arose from observations that some drugs blocking glutamatergic receptors can produce a psychosis more closely resembling schizophrenia than psychotomimetic drugs acting on other neurotransmitter systems(6-8). In addition, these drugs can exacerbate symptoms experienced by schizophrenia patients(9). Brain imaging studies reveal reduced glutamate in schizophrenia patients using magnetic resonance spectroscopy imaging (10-12). These findings have been consolidated by observations in postmortem brain, where specific changes in glutamate receptor expression and subunit composition have been detected in multiple brain regions of schizophrenia patients (13-41).

Glutamate is the primary excitatory neurotransmitter in the central nervous system within which glutamatergic neurons form a widely distributed network. Glutamate exerts its actions through ionotropic receptors which are classified as NMDA, AMPA and kainate subtypes, in addition to metabotropic receptors(42). Glutamatergic synapses also contain a distinctive web of proteins beneath their postsynaptic membranes, called the postsynaptic density (PSD), which interacts with the receptors, facilitating glutamatergic transmission. The dynamic rearrangement of dendritic spines and PSDs appears to be the structural basis for synaptic regulation and synaptic plasticity(43). Therefore, the regulation and functional interplay between PSD components leading to the alteration of synaptic structures makes these strong candidates for investigation in disorders associated with cognitive dysfunction, including schizophrenia. Proteins within the PSD include SynGAP, PSD-95, STARGAZIN, SAP97, SAP102, PICK1, GRIP1 and NF-L(44).

Abnormalities within the glutamatergic system have been extensively studied in schizophrenia patients $(13-41,45-47)$. Several prefrontal cortical regions are considered to be impaired in schizophrenia, including the dorsolateral prefrontal cortex (DLPFC) and the cingulate cortex(48). The thalamus is a critical subcortical structure linked to the cortex. While much of the pathophysiology of schizophrenia has been attributed to cortical dysfunction, disruption of reciprocal neuronal projections between the medial dorsal thalamus (MD) and frontal cortical areas is likely to impair the transmission of information between these two brain regions. Neuronal projections originating in the MD which terminate in the DLPFC and cingulate cortices are glutamatergic relay neurons. These cortical areas send projections to the caudate nucleus and nucleus accumbens, respectively(49).

Thalamic abnormalities have been identified in schizophrenia by multiple brain imaging studies. Reduced thalamic volume has been reported by several investigators, in addition to reduced metabolism in the thalamus (50-52). Thalamic hypofunction is thought to contribute to deficits of sensory processing in schizophrenia patients (53). Some stereological studies of postmortem brain have demonstrated a substantial loss of the neurons in the MD in schizophrenia but there have been conflicting data. It is estimated that $70 \%$ of these neurons are glutamatergic, suggesting that some glutamatergic neurons are included in the neuronal loss observed, which might be predicted to disrupt communication between the thalamus and the prefrontal cortex(48).

Studies of thalamic glutamatergic gene expression in schizophrenia have produced mixed results (54-62). However, investigations of whole thalamus and thalamic nuclei using in situ 
hybridization, semi-quantitative real time PCR (PCR), western blotting and receptor autoradiography have together suggested a reduction of glutamatergic gene expression in various thalamic nuclei, including the MD of schizophrenia patients(22, 24, 33, 63). Conflicting data between these studies may not be due to differences in measurements of protein and transcript, but rather due to cellular heterogeneity of the tissue tested.

In the current study, we have tested the expression of 35 genes of the glutamate system relative to several 'housekeeping' genes, specifically in a population of medial dorsal thalamic cells enriched for glutamatergic relay neurons compared to a population of smaller cells enriched for GABAergic neurons and astroglia, which were isolated using laser capture microdissection. Cell populations were identified using gene expression markers. We report reductions of a subset of glutamate associated transcripts in schizophrenia patients, which were restricted to the glutamatergic relay neurons of the MD and not in the smaller cell population enriched with GABAergic neurons and astroglia.

\section{Methods}

\section{Subjects}

Frozen postmortem brain tissue from the thalamus was obtained from two groups of subjects: (1) patients diagnosed by DSM-IV criteria (64) with schizophrenia (SCZ), but no other psychiatric co-morbidities; (2) a comparison group (NC) with no history of psychiatric or neurological disorders. Subjects were recruited by the Mount Sinai/Bronx Veterans Administration (VA) Medical Center Department of Psychiatry Brain Bank. All patients had thorough neuropathologic characterization to rule out neurodegenerative disorders including Alzheimer's disease (65). All subjects died of natural causes and without a history of alcoholism and/or substance abuse. The groups were matched for age, postmortem interval (PMI), tissue pH and sex, as shown in Table S1 in the Supplement. A total of 14 SCZ and 20 NC subjects were tested and not all genes were measurable in each subject. There was adequate statistical power to detect a difference between our subject groups with an effect size of 0.8 (www.danielsoper.com/statcalc). All assessment, consent and postmortem procedures were conducted as required by the Institutional Review Boards of Pilgrim Psychiatric Center, Mount Sinai School of Medicine and the Bronx VA Medical Center.

\section{Harvesting of cells and isolation of RNA from the medial dorsal thalamus}

Brains were obtained after autopsy and cut into $0.8-1 \mathrm{~cm}$ coronal slabs and stored at $-80^{\circ} \mathrm{C}$. Blocks including the medial dorsal nucleus of the thalamus from the left side of the brain of each subject were used in this study. To identify the thalamic nuclei, we used anatomical landmarks by comparison with adjacent in situ hybridization images from previous studies (Figure 1B)(63, 66-67), descriptions of thalamic architecture (68), and matched to brain atlases (69). Four adjacent $20 \mu \mathrm{m}$ sections including the medial dorsal nucleus, were mounted onto $1 \times 3$ inch penfoil polymer (PEN) or superfrost plus glass microdissection slides and stored at $-80^{\circ} \mathrm{C}$ before cell harvesting. Sections were incubated in $1 \%$ cresyl violet acetate for 2 minutes, submerged in $95 \%$ ethanol, then $100 \%$ ethanol for 30 seconds, followed by immersion in xylene for 5 minutes. This staining revealed large glutamatergic relay neurons in the medial dorsal thalamus (Figure 1A) with predicted gene expression profiles of neuronal and glial markers (Table 1, Figure 1C). 500-600 of these cells were isolated from each subject by laser capture microdissection using an Arcturus VERITAS instrument and protocols (http://www.moleculardevices.com/pages/instruments/veritas.html). 500-600 smaller cells, with morphology and gene expression patterns consistent with GABAergic neurons and astroglia, were also harvested (Figure 1). Investigation of the mixed small cell population was performed for the purposes of comparison. These cells were controls, because they were 
harvested using the same methodology as the large cells, and provided a more accurate control group than a tissue scrape. Total RNA was extracted using the PicoPure RNA isolation Kit (Molecular Devices, Sunnyvale, CA). RNA quality was evaluated using the Agilent 2100 BioAnalyzer (Agilent Technologies, Santa Clara, CA). Extraction procedures reliably produced average RNA integrity numbers (RIN) $\geq 7$ (Table S1 in the Supplement). 'Test slides' simulated the effects of the LCM process including Nissl staining and a time delay of 3 hours at room temperature before RNA integrity (RIN) was measured (70). All section/cells harvested using LCM were processed in the same manner; thus differences between the diagnostic groups are unlikely to be secondary to a processing effect. We have included RIN measurements for each of the samples in Table S1 in the Supplement.

cDNA was synthesized from equal quantities of RNA from each subject, by the reverse transcriptase (RT) reaction using the High Capacity cDNA Reverse Transcription Kit (Applied Biosystems, Foster City, CA). Aliquots of cDNA from each subject were pooled for use as standards, with dilutions of 1:20, 1:10, 1:5 and undiluted pooled cDNA used to generate a calibration curve according to the relative standard curve method for gene expression analysis (www.AppliedBiosystems.com).

\section{Preamplification of cDNA from laser captured cells}

A preamplification step was required due to the low starting concentration of mRNA (diluted to a final concentration of $20 \mathrm{ng}$ per microliter) after RNA was extracted (71) from 500-600 laser capture micro-dissected cells per subject using the Arcturus protocol. All TaqMan assays intended for gene expression analysis were combined in equal volumes to a final volume of $12.5 \mu \mathrm{l}$ so that each assay was diluted 1 in 10 in TE buffer. This mixture was added to $12.5 \mu \mathrm{l}$ of cDNA and $25 \mu \mathrm{l}$ of TaqMan Preamp Master Mix (Applied Biosystems). Samples were centrifuged and amplified in a thermal cycler (BioRad) for $1 \mathrm{cycle}$ of $95^{\circ} \mathrm{C}$ for 10 minutes, and then 14 cycles of $95^{\circ} \mathrm{C}$ for 15 seconds and $60^{\circ} \mathrm{C}$ for 4 minutes.

\section{Gene expression assays}

Primers and probes used were standard proprietary assays designed by Applied Biosystems, for which detailed information can be found at their website: https://products.appliedbiosystems.com/ab/en/US/adirect/ab? cmd=ABGEKeywordSearch\&catID=601267 and are listed in Table S2 in the Supplement. TaqMan PCR assays for each target gene were performed in duplicate on cDNA samples in 96-well optical plates on a Stratagene MX3000P (Stratagene, La Jolla, CA). All TaqMan PCR data were captured using Sequence Detector Software (SDS version 1.6; PE Applied Biosystems). For every sample, an amplification plot was generated, showing the increase in the reporter dye fluorescence with each cycle of PCR. ACTB, B2M and GAPDH were stably expressed in the samples tested and were used as standards with which we calculated ratios of gene expression for each test transcript. The geometric mean of their expression levels was used for normalization, since averaging of multiple internal control genes has greater accuracy than calculations from single housekeeping genes(72). The relative expression levels of test transcripts were calculated using the Relative Standard Curve Method according to Applied Biosystems instructions (Guide to Performing Relative Quantitation of Gene Expression Using Real-time Quantitative PCR, Applied Biosystems). Standard curves were generated for each target assay and for each endogenous control assay using a 'calibration curve'. The curve was generated from measurements of a mixture of serial dilutions of a pool of all experimental samples. Using the linear equations of standard curves, the amounts of each mRNA were calculated. The relative expression level of a target mRNA was computed as the ratio of the target mRNA amount to the geometric mean of the amounts of the three endogenous controls. 


\section{Statistical analysis}

Our hypothesis was that glutamatergic dysfunction occurs in schizophrenia, and to test this we conducted a two-way ANCOVA, grouping data by diagnosis and candidate gene (SPSS v 18, SPSS Inc, Chicago, IL). Post-hoc tests were primarily Student's t test and Levene's test for equality of variances. Where variances were significantly different between cases and controls, the $t$ value reported did not assume equal variances. Age, postmortem interval (PMI) and $\mathrm{pH}$ were considered as potential covariates. Comparisons made were the expression level of each gene, with diagnosis as a classification variable. Age at death, PMI and $\mathrm{pH}$ were included as covariates if correlated with gene expression using Pearson's correlation coefficient.

\section{Results}

Glutamatergic relay neurons were enriched in the large cell population. High levels of vesicular glutamate transporter 2 (VGLUT2) were detected in the large cell populations, but not in the small cell populations sampled from each subject. There were much lower levels of GFAP and GAD-67 in the large cell population in contrast with the small cell population from each subject (Table 1, Figure 1C). High expression levels of VGLUT2 are specific to glutamatergic neurons (73-74), while GFAP and GAD-67 are specific to astroglia and GABAergic cells respectively (75-76). Neuron specific enolase (NSE) expression is expected in all neurons (77). Therefore our finding of higher levels of NSE in the large cell population in comparison with the small cell population, suggests that the small cell population is a mixture of both GABAergic cells and astroglia. These data are summarized in Table 1 and Figure 1C.

Having confirmed that the large cell population was indeed enriched with glutamate neurons, and that the small cell population was enriched with astrocytes and GABAergic neurons, we measured the expression of genes associated with glutamatergic neurotransmission in these two cell populations.

Our hypothesis was that glutamatergic dysfunction occurs in schizophrenia, and to test this we conducted a two-way ANCOVA, grouping data by diagnosis and candidate gene, and our results indicate that there is an overall reduction in glutamatergic transcript level in the large cell population in the schizophrenia cases relative to the comparison group $(\mathrm{F}=18.05$, $\mathrm{df}=1,64, \mathrm{p}=0.00003$ ). In contrast, there were no significant differences in glutamatergic transcript level between the diagnostic groups in the small cell population.

Data from post-hoc tests are summarized in Table 2. Our measurements of transcript abundance in the large cell population indicated an overall reduction of all ionotropic glutamate receptor subunits and postsynaptic density proteins, but not metabotropic glutamate receptors, in schizophrenia subjects relative to the comparison group (illustrated in Figure 2). Reductions reaching statistical significance ( $\mathrm{p} \leq 0.05)$ were detected for GluR3, GluR6, GluR7, NR2D, GRIP1 and SynGAP1. In contrast, these transcripts were not found to differ in the small cell population. RIN, $\mathrm{pH}$ and other demographic variables (Table $\mathrm{S} 1$ in the Supplement) were not associated with diagnosis or gene expression. No significant differences were observed between the genders in any of the variables tested, and therefore we considered it appropriate to combine the males and females in each diagnostic group. There were slightly more subjects in the comparison group (18-20) than in the patient group $(12-14)$ but we retained approximately $71 \%$ statistical power in the study to detect large effect sizes (0.8). 


\section{Discussion}

This study demonstrates that reduced glutamatergic gene expression occurs specifically in the relay neurons of the medial dorsal thalamus in schizophrenia. When individual genes are considered, our data show (1) significant reductions in GluR3 (an AMPA receptor subunit), GluR6 and GluR7 (kainate receptor subunits), NR2D (an NMDA receptor subunit), GRIP1 and SynGAP transcripts (PSD proteins) in thalamocortical relay neurons in schizophrenia; (2) no alteration of mGluR expression in either cell population; and (3) enrichment of specific cell populations can be performed successfully in the thalamus using morphological features combined with gene expression analysis of neuronal and glial markers combined with laser capture microscopy.

Our findings of reduced glutamatergic gene expression in thalamocortical neurons suggest that the circuitry required for communication between the thalamus and frontal cortex is dysfunctional in schizophrenia. These effects were not observed in the astroglia and GABAergic cells which remain local to the thalamus, suggesting that the deficiency is specific to thalamocortical circuitry and not due to a general defect of all cells of the thalamus.

The glutamate hypothesis of schizophrenia proposes that altered glutamatergic activity may underlie the pathophysiology of the disorder, which originated from observations of schizophreniform psychosis on administration of non-competitive NMDA receptor antagonists such as phencyclidine to normal subjects(6). Many other observations have subsequently supported the hypothesis that glutamatergic hypofunction is psychotomimetic, including the current data, which indicate that a reduction of glutamatergic gene expression occurs in the MD in schizophrenia. Our experiments revealed that proteins involved in ionotropic glutamatergic transmission had the greatest reductions in transcript levels in schizophrenia. This finding was specific to the glutamate neurons of the MD, and not in the astroglia and small GABAergic neurons. These data indicate that cell-specific changes occur in glutamatergic transmission in the medial dorsal thalamus in schizophrenia. These cellspecific effects may explain discrepancies with a previously published study of whole thalamic nuclei where no differences were detected between schizophrenia cases relative to a comparison group (61).

The ionotropic glutamate receptors interact physiologically and therefore our findings of reduced expression of AMPA and kainate receptor subunits in schizophrenia relative to the comparison group is not surprising, because a primary deficit in either NMDA or AMPA function could lead to a secondary downregulation of other glutamate receptors. Activation of AMPARs is necessary to remove the magnesium ion blockade of the NMDAR ion channel, which precedes NMDAR activation and subsequent depolarization of the postsynaptic neurons(86). Reduced expression of AMPAR subunits, leading to reduced AMPAR activity, may lead to altered glutamatergic transmission which has been shown to produce psychosis. Our post-hoc findings revealed reductions of both GluR3 and an AMPAR-associated PSD protein, GRIP1 in schizophrenia.

Our post-hoc findings indicate that several ionotropic receptor subunit transcripts were reduced in schizophrenia in addition to reduced SynGAP expression. SynGAP is a PSD protein associated with NMDAR signal transduction which is interesting because SynGAP mutant mice have non-habituating and persistent hyperactivity, enhanced startle reactivity, impaired sensorimotor gating, altered social behavior, in addition to deficits in cued fear conditioning and working memory which are similar to other mouse models of schizophrenia(78). Similar abnormal behaviors which could model some features of schizophrenia have been observed in mice engineered with reduced NMDAR function(79- 
82). Our data also indicate reduced expression of NR2D subunits of NMDARs, which are thought to confer greatest activity to the NMDAR complex (84-85). Our gene expression data are generally in concordance with studies showing reduced NMDAR protein levels inferred from receptor autoradiography. However, our cell-specific findings for reduced NR2D expression in schizophrenia have not been previously reported in studies using in situ hybridization $(22,63)$ or semi-quantitative PCR $(61)$ which may be due to differing sensitivities of the methods employed. Our data support the large body of converging evidence that schizophrenia could be associated with abnormalities of NMDAR signal transduction. Our post-hoc analyses also indicate reduced expression of the kainate receptor subunits GluR6 and GluR7. These reductions could be secondary to NMDAR deficits or vice versa. Chronic administration of phencyclidine, or PCP, which blocks the NMDAR ion channel and has been shown to induce psychosis(87), also appears to decrease GluR2, GluR3, GluR5 and GluR6 expression in rat prefrontal cortex(88), suggesting that a primary reduction of NMDAR signaling can cause secondary reductions in the expression levels of non-NMDAR subunits.

Reduced fast excitatory transmission in the thalamocortical circuitry between the MD and prefrontal cortex could be the consequence of reduced ionotropic glutamatergic gene expression in the relay neurons from the MD. These relay neurons project to the prefrontal cortex, a region which is considered to be impaired in schizophrenia, leading to deficits in executive function (48). Our data indicate that slow transmission from metabotropic glutamate receptors is less likely to be involved since levels of mGluR transcripts were unchanged in these cells in schizophrenia.

Our data show gene expression differences between cell populations, which may obscure measurements of transcriptional variation in regional studies of gene expression using tissue homogenates, whole nuclei or sections. We report reduced levels of several glutamate receptor transcripts and PSD proteins, specifically in large glutamate cells of the medial dorsal thalamus and not in other cells. The other cells tested ('small cells') comprised a mixed population of astroglia and GABAergic interneurons. While this is an extensive study and provides gene expression data with anatomical specificity, there remain some limitations of this approach. As ever with postmortem studies of schizophrenia, there may be confounding effects due to antipsychotic treatment received by the patients and not the controls. Further, we used assays to measure transcript abundance which did not take into account post-transcriptional variation and therefore isoform differences between the proteins investigated. Measurements of transcript alone may infer gene expression changes in schizophrenia, but mechanistically measurements of protein abundance are required to confirm that protein activity is likely to be reduced. Measuring protein levels in LCMderived tissue is currently not possible in small anatomical regions due to limitations in tissue quantity. We estimate that 10,000 cells would be required to measure glutamate receptor proteins in these subjects by conventional methods, because proteins cannot be amplified before measurement.

In summary, we have found cell-specific reductions in glutamate receptor transcripts in the MD of schizophrenia subjects relative to a comparison group, specifically in a subset of NMDA, AMPA and kainate receptor subunits, and the PSD proteins SynGAP and GRIP1. These data indicate that dysfunction of glutamate neurotransmission occurs specifically within the neurons giving rise to the projections of the MD to the frontal cortex in schizophrenia, rather than in astroglia or GABAergic neurons, which remain intrinsically local to, and do not send projections from, the thalamus. Thus we suggest that these data reflect an abnormality in schizophrenia of thalamocortical circuitry rather than a global defect of all the cells in the thalamus. Further investigation of protein abundance, trafficking 
and post-transcriptional variation of the candidate genes associated with schizophrenia is required to clarify these findings.

\section{Supplementary Material}

Refer to Web version on PubMed Central for supplementary material.

\section{Acknowledgments}

The authors thank Jana Drummond for technical assistance. Work funded by NIH MH070895 (JMW) and MH066392 (VH).

\section{References}

1. Krystal JH, Karper LP, Seibyl JP, Freeman GK, Delaney R, Bremner JD, et al. Subanesthetic effects of the noncompetitive NMDA antagonist, ketamine, in humans. Psychotomimetic, perceptual, cognitive, and neuroendocrine responses. Arch Gen Psychiatry. 1994; 51:199-214. [PubMed: 8122957]

2. Olney JW, Farber NB. Glutamate receptor dysfunction and schizophrenia. Arch Gen Psychiatry. 1995; 52:998-1007. [PubMed: 7492260]

3. Coyle JT. The glutamatergic dysfunction hypothesis for schizophrenia. Harv Rev Psychiatry. 1996; 3:241-253. [PubMed: 9384954]

4. Javitt DC. Negative schizophrenic symptomatology and the PCP (phencyclidine) model of schizophrenia. Hillside J Clin Psychiatry. 1987; 9:12-35. [PubMed: 2820854]

5. Sodhi M, Wood KH, Meador-Woodruff J. Role of glutamate in schizophrenia: integrating excitatory avenues of research. Expert Rev Neurother. 2008; 8:1389-1406. [PubMed: 18759551]

6. Luby ED, Cohen BD, Rosenbaum G, Gottlieb JS, Kelley R. Study of a new schizophrenomimetic drug; sernyl. AMA Arch Neurol Psychiatry. 1959; 81:363-369.

7. Rosenbaum G, Cohen BD, Luby ED, Gottlieb JS, Yelen D. Comparison of sernyl with other drugs: simulation of schizophrenic performance with sernyl, LSD-25, and amobarbital (amytal) sodium; I. Attention, motor function, and proprioception. Arch Gen Psychiatry. 1959; 1:651-656. [PubMed: 14438905]

8. Cohen BD, Rosenbaum G, Luby ED, Gottlieb JS. Comparison of phencyclidine hydrochloride (Sernyl) with other drugs. Simulation of schizophrenic performance with phencyclidine hydrochloride (Sernyl), lysergic acid diethylamide (LSD-25), and amobarbital (Amytal) sodium; II. Symbolic and sequential thinking. Arch Gen Psychiatry. 1962; 6:395-401. [PubMed: 13880223]

9. Lahti AC, Koffel B, LaPorte D, Tamminga CA. Subanesthetic doses of ketamine stimulate psychosis in schizophrenia. Neuropsychopharmacology. 1995; 13:9-19. [PubMed: 8526975]

10. Bartha R, Williamson PC, Drost DJ, Malla A, Carr TJ, Cortese L, et al. Measurement of glutamate and glutamine in the medial prefrontal cortex of never-treated schizophrenic patients and healthy controls by proton magnetic resonance spectroscopy. Arch Gen Psychiatry. 1997; 54:959-965. [PubMed: 9337777]

11. Omori M, Pearce J, Komoroski RA, Griffin WS, Mrak RE, Husain MM, et al. In vitro 1Hmagnetic resonance spectroscopy of postmortem brains with schizophrenia. Biol Psychiatry. 1997; 42:359-366. [PubMed: 9276076]

12. Theberge J, Al-Semaan Y, Williamson PC, Menon RS, Neufeld RW, Rajakumar N, et al. Glutamate and glutamine in the anterior cingulate and thalamus of medicated patients with chronic schizophrenia and healthy comparison subjects measured with 4.0-T proton MRS. Am J Psychiatry. 2003; 160:2231-2233. [PubMed: 14638596]

13. Deakin JF, Slater P, Simpson MD, Gilchrist AC, Skan WJ, Royston MC, et al. Frontal cortical and left temporal glutamatergic dysfunction in schizophrenia. J Neurochem. 1989; 52:1781-1786. [PubMed: 2566649]

14. Squires RF, Lajtha A, Saederup E, Palkovits M. Reduced [3H]flunitrazepam binding in cingulate cortex and hippocampus of postmortem schizophrenic brains: is selective loss of glutamatergic 
neurons associated with major psychoses? Neurochem Res. 1993; 18:219-223. [PubMed: 8097289]

15. Ishimaru M, Kurumaji A, Toru M. Increases in strychnine-insensitive glycine binding sites in cerebral cortex of chronic schizophrenics: evidence for glutamate hypothesis. Biol Psychiatry. 1994; 35:84-95. [PubMed: 7909453]

16. Breese CR, Freedman R, Leonard SS. Glutamate receptor subtype expression in human postmortem brain tissue from schizophrenics and alcohol abusers. Brain Res. 1995; 674:82-90. [PubMed: 7773698]

17. Humphries C, Mortimer A, Hirsch S, de Belleroche J. NMDA receptor mRNA correlation with antemortem cognitive impairment in schizophrenia. Neuroreport. 1996; 7:2051-2055. [PubMed: 8905723]

18. Eastwood SL, Kerwin RW, Harrison PJ. Immunoautoradiographic evidence for a loss of alphaamino-3-hydroxy-5-methyl-4-isoxazole propionate-preferring non-N-methyl-D-aspartate glutamate receptors within the medial temporal lobe in schizophrenia. Biol Psychiatry. 1997; 41:636-643. [PubMed: 9066986]

19. Meador-Woodruff JH, Healy DJ. Glutamate receptor expression in schizophrenic brain. Brain Res Brain Res Rev. 2000; 31:288-294. [PubMed: 10719155]

20. Sokolov BP. Expression of NMDAR1, GluR1, GluR7, and KA1 glutamate receptor mRNAs is decreased in frontal cortex of "neuroleptic-free" schizophrenics: evidence on reversible upregulation by typical neuroleptics. J Neurochem. 1998; 71:2454-2464. [PubMed: 9832144]

21. Gao XM, Sakai K, Roberts RC, Conley RR, Dean B, Tamminga CA. Ionotropic glutamate receptors and expression of N-methyl-D-aspartate receptor subunits in subregions of human hippocampus: effects of schizophrenia. Am J Psychiatry. 2000; 157:1141-1149. [PubMed: 10873924]

22. Ibrahim HM, Hogg AJ Jr, Healy DJ, Haroutunian V, Davis KL, Meador-Woodruff JH. Ionotropic glutamate receptor binding and subunit mRNA expression in thalamic nuclei in schizophrenia. Am J Psychiatry. 2000; 157:1811-1823. [PubMed: 11058479]

23. Ohnuma T, Tessler S, Arai H, Faull RL, McKenna PJ, Emson PC. Gene expression of metabotropic glutamate receptor 5 and excitatory amino acid transporter 2 in the schizophrenic hippocampus. Brain Res Mol Brain Res. 2000; 85:24-31. [PubMed: 11146103]

24. Richardson-Burns SM, Haroutunian V, Davis KL, Watson SJ, Meador-Woodruff JH. Metabotropic glutamate receptor mRNA expression in the schizophrenic thalamus. Biol Psychiatry. 2000; 47:22-28. [PubMed: 10650445]

25. Benes FM, Todtenkopf MS, Kostoulakos P. GluR5,6,7 subunit immunoreactivity on apical pyramidal cell dendrites in hippocampus of schizophrenics and manic depressives. Hippocampus. 2001; 11:482-491. [PubMed: 11732702]

26. Dracheva S, Marras SA, Elhakem SL, Kramer FR, Davis KL, Haroutunian V. N-methyl-D-aspartic acid receptor expression in the dorsolateral prefrontal cortex of elderly patients with schizophrenia. Am J Psychiatry. 2001; 158:1400-1410. [PubMed: 11532724]

27. Meador-Woodruff JH, Davis KL, Haroutunian V. Abnormal kainate receptor expression in prefrontal cortex in schizophrenia. Neuropsychopharmacology. 2001; 24:545-552. [PubMed: $11282254]$

28. Hemby SE, Ginsberg SD, Brunk B, Arnold SE, Trojanowski JQ, Eberwine JH. Gene expression profile for schizophrenia: discrete neuron transcription patterns in the entorhinal cortex. Arch Gen Psychiatry. 2002; 59:631-640. [PubMed: 12090816]

29. Noga JT, Wang H. Further postmortem autoradiographic studies of AMPA receptor binding in schizophrenia. Synapse. 2002; 45:250-258. [PubMed: 12125046]

30. Zavitsanou K, Ward PB, Huang XF. Selective alterations in ionotropic glutamate receptors in the anterior cingulate cortex in schizophrenia. Neuropsychopharmacology. 2002; 27:826-833. [PubMed: 12431856]

31. Harrison PJ, Law AJ, Eastwood SL. Glutamate receptors and transporters in the hippocampus in schizophrenia. Ann N Y Acad Sci. 2003; 1003:94-101. [PubMed: 14684437] 
32. Lewis DA, Glantz LA, Pierri JN, Sweet RA. Altered cortical glutamate neurotransmission in schizophrenia: evidence from morphological studies of pyramidal neurons. Ann N Y Acad Sci. 2003; 1003:102-112. [PubMed: 14684438]

33. Meador-Woodruff JH, Clinton SM, Beneyto M, McCullumsmith RE. Molecular abnormalities of the glutamate synapse in the thalamus in schizophrenia. Ann N Y Acad Sci. 2003; 1003:75-93. [PubMed: 14684436]

34. Dracheva S, McGurk SR, Haroutunian V. mRNA expression of AMPA receptors and AMPA receptor binding proteins in the cerebral cortex of elderly schizophrenics. J Neurosci Res. 2005; 79:868-878. [PubMed: 15696539]

35. Gupta DS, McCullumsmith RE, Beneyto M, Haroutunian V, Davis KL, Meador-Woodruff JH. Metabotropic glutamate receptor protein expression in the prefrontal cortex and striatum in schizophrenia. Synapse. 2005; 57:123-131. [PubMed: 15945063]

36. Kristiansen LV, Meador-Woodruff JH. Abnormal striatal expression of transcripts encoding NMDA interacting PSD proteins in schizophrenia, bipolar disorder and major depression. Schizophr Res. 2005; 78:87-93. [PubMed: 16023328]

37. Mexal S, Frank M, Berger R, Adams CE, Ross RG, Freedman R, et al. Differential modulation of gene expression in the NMDA postsynaptic density of schizophrenic and control smokers. Brain Res Mol Brain Res. 2005; 139:317-332. [PubMed: 16122832]

38. Newell KA, Zavitsanou K, Huang XF. Ionotropic glutamate receptor binding in the posterior cingulate cortex in schizophrenia patients. Neuroreport. 2005; 16:1363-1367. [PubMed: 16056140]

39. Beneyto M, Kristiansen LV, Oni-Orisan A, McCullumsmith RE, Meador-Woodruff JH. Abnormal glutamate receptor expression in the medial temporal lobe in schizophrenia and mood disorders. Neuropsychopharmacology. 2007; 32:1888-1902. [PubMed: 17299517]

40. Corti C, Crepaldi L, Mion S, Roth AL, Xuereb JH, Ferraguti F. Altered dimerization of metabotropic glutamate receptor 3 in schizophrenia. Biol Psychiatry. 2007; 62:747-755. [PubMed: 17531207]

41. McCullumsmith RE, Kristiansen LV, Beneyto M, Scarr E, Dean B, Meador-Woodruff JH. Decreased NR1, NR2A, and SAP102 transcript expression in the hippocampus in bipolar disorder. Brain Res. 2007; 1127:108-118. [PubMed: 17113057]

42. Lodge D. The history of the pharmacology and cloning of ionotropic glutamate receptors and the development of idiosyncratic nomenclature. Neuropharmacology. 2009; 56:6-21. [PubMed: 18765242]

43. Carlisle HJ, Kennedy MB. Spine architecture and synaptic plasticity. Trends Neurosci. 2005; 28:182-187. [PubMed: 15808352]

44. Kennedy MB. The postsynaptic density at glutamatergic synapses. Trends Neurosci. 1997; 20:264268. [PubMed: 9185308]

45. Goff DC, Coyle JT. The emerging role of glutamate in the pathophysiology and treatment of schizophrenia. Am J Psychiatry. 2001; 158:1367-1377. [PubMed: 11532718]

46. Eastwood SL, Burnet PW, Harrison PJ. GluR2 glutamate receptor subunit flip and flop isoforms are decreased in the hippocampal formation in schizophrenia: a reverse transcriptase-polymerase chain reaction (RT-PCR) study. Brain Res Mol Brain Res. 1997; 44:92-98. [PubMed: 9030702]

47. Benes FM, Sorensen I, Vincent SL, Bird ED, Sathi M. Increased density of glutamateimmunoreactive vertical processes in superficial laminae in cingulate cortex of schizophrenic brain. Cereb Cortex. 1992; 2:503-512. [PubMed: 1282404]

48. Pakkenberg B, Scheel-Kruger J, Kristiansen LV. Schizophrenia; from structure to function with special focus on the mediodorsal thalamic prefrontal loop. Acta Psychiatr Scand. 2009; 120:345354. [PubMed: 19807715]

49. Jones EG. Cortical development and thalamic pathology in schizophrenia. Schizophr Bull. 1997; 23:483-501. [PubMed: 9327511]

50. Ellison-Wright I, Glahn DC, Laird AR, Thelen SM, Bullmore E. The anatomy of first-episode and chronic schizophrenia: an anatomical likelihood estimation meta-analysis. Am J Psychiatry. 2008; 165:1015-1023. [PubMed: 18381902] 
51. Szulc A, Galinska B, Tarasow E, Dzienis W, Kubas B, Konarzewska B, et al. The effect of risperidone on metabolite measures in the frontal lobe, temporal lobe, and thalamus in schizophrenic patients. A proton magnetic resonance spectroscopy (1H MRS).

Pharmacopsychiatry. 2005; 38:214-219. [PubMed: 16189748]

52. Theberge J, Bartha R, Drost DJ, Menon RS, Malla A, Takhar J, et al. Glutamate and glutamine measured with 4.0 T proton MRS in never-treated patients with schizophrenia and healthy volunteers. Am J Psychiatry. 2002; 159:1944-1946. [PubMed: 12411236]

53. Ettinger U, Picchioni M, Landau S, Matsumoto K, van Haren NE, Marshall N, et al. Magnetic resonance imaging of the thalamus and adhesio interthalamica in twins with schizophrenia. Arch Gen Psychiatry. 2007; 64:401-409. [PubMed: 17404117]

54. Byne W, Buchsbaum MS, Mattiace LA, Hazlett EA, Kemether E, Elhakem SL, et al. Postmortem assessment of thalamic nuclear volumes in subjects with schizophrenia. Am J Psychiatry. 2002; 159:59-65. [PubMed: 11772691]

55. Kemether EM, Buchsbaum MS, Byne W, Hazlett EA, Haznedar M, Brickman AM, et al. Magnetic resonance imaging of mediodorsal, pulvinar, and centromedian nuclei of the thalamus in patients with schizophrenia. Archives of general psychiatry. 2003; 60:983-991. [PubMed: 14557143]

56. Popken GJ, Bunney WE Jr, Potkin SG, Jones EG. Subnucleus-specific loss of neurons in medial thalamus of schizophrenics. Proceedings of the National Academy of Sciences of the United States of America. 2000; 97:9276-9280. [PubMed: 10908653]

57. Young KA, Manaye KF, Liang C, Hicks PB, German DC. Reduced number of mediodorsal and anterior thalamic neurons in schizophrenia. Biological psychiatry. 2000; 47:944-953. [PubMed: 10838062]

58. Cullen TJ, Walker MA, Parkinson N, Craven R, Crow TJ, Esiri MM, et al. A postmortem study of the mediodorsal nucleus of the thalamus in schizophrenia. Schizophrenia research. 2003; 60:157166. [PubMed: 12591579]

59. Dorph-Petersen KA, Pierri JN, Sun Z, Sampson AR, Lewis DA. Stereological analysis of the mediodorsal thalamic nucleus in schizophrenia: volume, neuron number, and cell types. The Journal of comparative neurology. 2004; 472:449-462. [PubMed: 15065119]

60. Young KA, Holcomb LA, Yazdani U, Hicks PB, German DC. Elevated neuron number in the limbic thalamus in major depression. The American journal of psychiatry. 2004; 161:1270-1277. [PubMed: 15229061]

61. Dracheva S, Byne W, Chin B, Haroutunian V. Ionotropic glutamate receptor mRNA expression in the human thalamus: absence of change in schizophrenia. Brain research. 2008; 1214:23-34. [PubMed: 18462708]

62. Watis L, Chen SH, Chua HC, Chong SA, Sim K. Glutamatergic abnormalities of the thalamus in schizophrenia: a systematic review. J Neural Transm. 2008

63. Clinton SM, Meador-Woodruff JH. Thalamic dysfunction in schizophrenia: neurochemical, neuropathological, and in vivo imaging abnormalities. Schizophrenia research. 2004; 69:237-253. [PubMed: 15469196]

64. Harvey J, Palmer MJ, Irving AJ, Clarke VR, Collingridge GL. NMDA receptor dependence of mGlu-mediated depression of synaptic transmission in the CA1 region of the rat hippocampus. $\mathrm{Br}$ J Pharmacol. 1996; 119:1239-1247. [PubMed: 8937729]

65. Purohit DP, Perl DP, Haroutunian V, Powchik P, Davidson M, Davis KL. Alzheimer disease and related neurodegenerative diseases in elderly patients with schizophrenia: a postmortem neuropathologic study of 100 cases. Arch Gen Psychiatry. 1998; 55:205-211. [PubMed: 9510214]

66. Clinton SM, Meador-Woodruff JH. Abnormalities of the NMDA Receptor and Associated Intracellular Molecules in the Thalamus in Schizophrenia and Bipolar Disorder. Neuropsychopharmacology. 2004; 29:1353-1362. [PubMed: 15054476]

67. Clinton SM, Haroutunian V, Meador-Woodruff JH. Up-regulation of NMDA receptor subunit and post-synaptic density protein expression in the thalamus of elderly patients with schizophrenia. Journal of neurochemistry. 2006; 98:1114-1125. [PubMed: 16762023]

68. Jones EG. Functional subdivision and synaptic organization of the mammalian thalamus. Int Rev Physiol. 1981; 25:173-245. [PubMed: 6110641] 
69. Hirai T, Jones EG. Distribution of tachykinin- and enkephalin-immunoreactive fibers in the human thalamus. Brain Res Brain Res Rev. 1989; 14:35-52. [PubMed: 2720230]

70. Schroeder A, Mueller O, Stocker S, Salowsky R, Leiber M, Gassmann M, et al. The RIN: an RNA integrity number for assigning integrity values to RNA measurements. BMC Mol Biol. 2006; 7:3. [PubMed: 16448564]

71. Mengual L, Burset M, Marin-Aguilera M, Ribal MJ, Alcaraz A. Multiplex preamplification of specific cDNA targets prior to gene expression analysis by TaqMan Arrays. BMC Res Notes. 2008; 1:21. [PubMed: 18710479]

72. Vandesompele J, De Preter K, Pattyn F, Poppe B, Van Roy N, De Paepe A, et al. Accurate normalization of real-time quantitative RT-PCR data by geometric averaging of multiple internal control genes. Genome Biol. 2002; 3:00-34.

73. Graziano A, Liu XB, Murray KD, Jones EG. Vesicular glutamate transporters define two sets of glutamatergic afferents to the somatosensory thalamus and two thalamocortical projections in the mouse. J Comp Neurol. 2008; 507:1258-1276. [PubMed: 18181146]

74. Nahmani M, Erisir A. VGluT2 immunochemistry identifies thalamocortical terminals in layer 4 of adult and developing visual cortex. J Comp Neurol. 2005; 484:458-473. [PubMed: 15770654]

75. Antanitus DS, Choi BH, Lapham LW. Immunofluorescence staining of astrocytes in vitro using antiserum to glial fibrillary acidic protein. Brain Res. 1975; 89:363-367. [PubMed: 1097056]

76. Kaufman DL, Houser CR, Tobin AJ. Two forms of the gamma-aminobutyric acid synthetic enzyme glutamate decarboxylase have distinct intraneuronal distributions and cofactor interactions. J Neurochem. 1991; 56:720-723. [PubMed: 1988566]

77. Schmechel D, Marangos PJ, Zis AP, Brightman M, Goodwin FK. Brain endolases as specific markers of neuronal and glial cells. Science. 1978; 199:313-315. [PubMed: 339349]

78. Rumbaugh G, Adams JP, Kim JH, Huganir RL. SynGAP regulates synaptic strength and mitogenactivated protein kinases in cultured neurons. Proc Natl Acad Sci U S A. 2006; 103:4344-4351. [PubMed: 16537406]

79. Bickel S, Javitt DC. Neurophysiological and neurochemical animal models of schizophrenia: focus on glutamate. Behav Brain Res. 2009; 204:352-362. [PubMed: 19433116]

80. Nabeshima T, Mouri A, Murai R, Noda Y. Animal model of schizophrenia: dysfunction of NMDA receptor-signaling in mice following withdrawal from repeated administration of phencyclidine. Ann N Y Acad Sci. 2006; 1086:160-168. [PubMed: 17185514]

81. Duncan EJ, Szilagyi S, Schwartz MP, Bugarski-Kirola D, Kunzova A, Negi S, et al. Effects of Dcycloserine on negative symptoms in schizophrenia. Schizophr Res. 2004; 71:239-248. [PubMed: 15474895]

82. Mohn AR, Gainetdinov RR, Caron MG, Koller BH. Mice with reduced NMDA receptor expression display behaviors related to schizophrenia. Cell. 1999; 98:427-436. [PubMed: 10481908]

83. Kim CH, Takamiya K, Petralia RS, Sattler R, Yu S, Zhou W, et al. Persistent hippocampal CA1 LTP in mice lacking the C-terminal PDZ ligand of GluR1. Nat Neurosci. 2005; 8:985-987. [PubMed: 16007085]

84. Monyer H, Sprengel R, Schoepfer R, Herb A, Higuchi M, Lomeli H, et al. Heteromeric NMDA receptors: molecular and functional distinction of subtypes. Science. 1992; 256:1217-1221. [PubMed: 1350383]

85. Kuner T, Schoepfer R. Multiple structural elements determine subunit specificity of $\mathrm{Mg} 2+$ block in NMDA receptor channels. J Neurosci. 1996; 16:3549-3558. [PubMed: 8642401]

86. Marambaud P, Dreses-Werringloer U, Vingtdeux V. Calcium signaling in neurodegeneration. Mol Neurodegener. 2009; 4:20. [PubMed: 19419557]

87. Farber NB. The NMDA receptor hypofunction model of psychosis. Ann N Y Acad Sci. 2003; 1003:119-130. [PubMed: 14684440]

88. Barbon A, Fumagalli F, La Via L, Caracciolo L, Racagni G, Riva MA, et al. Chronic phencyclidine administration reduces the expression and editing of specific glutamate receptors in rat prefrontal cortex. Experimental Neurology. 2007; 208:54-62. [PubMed: 17706642] 


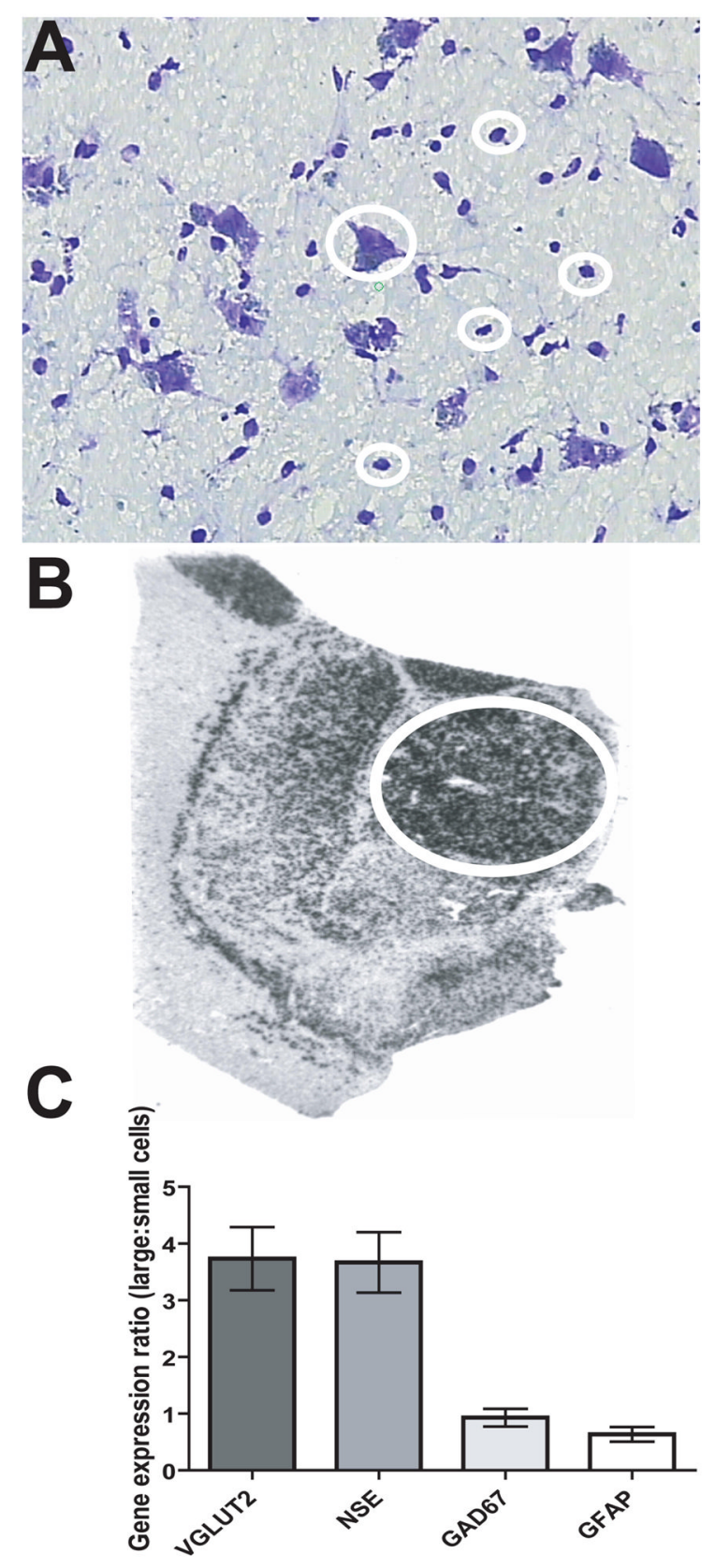

Figure 1. Gene expression studies of human postmortem thalamus

(A) Nissl stained slides of frozen postmortem tissue distinctly reveal large glutamatergic cells consistent with relay neurons in this region. An example of a large cell is encircled in the center of the photomicrograph, and four small cells are also indicated. The latter were a mixture of GABA interneurons and astroglia, which were harvested separately. (B) An autoradiographic image of a section of thalamus labeled with a radioactive riboprobe specific for GAD67 transcript. The medial dorsal (encircled) and lateral and ventral thalamic regions are distinct. (C) The expression of VGLUT2, NSE, GFAP and GAD67 transcripts in large cell sample relative to small cells. Large/small cell expression levels of VGLUT2 was $>1$, as expected, because VGLUT2 is only expressed in glutamatergic cells. In addition, GAD67 and GFAP were mostly absent in large cells, while NSE was similarly expressed in large and small cells captured. These data indicate that the large cells are enriched for 
glutamatergic relay neurons and the small cell population is enriched for GABAergic neurons and astrocytes. 


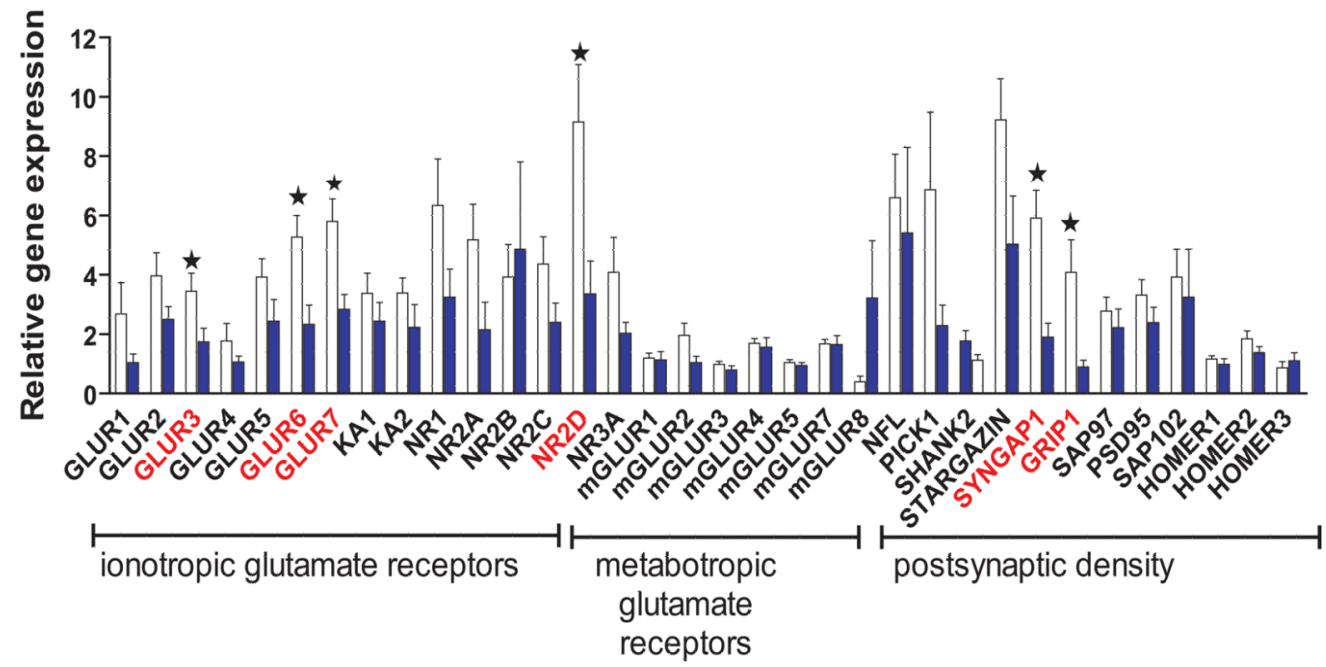

Figure 2. Gene expression in glutamatergic relay neurons of the medial dorsal thalamus in schizophrenia patients relative to comparison subjects

Mean gene expression (ratio of measured transcript level to the geometric mean of the measurements for three housekeeping genes) is plotted for each glutamatergic candidate gene within each subject group. The white bars represent the comparison group and shaded bars represent the schizophrenia subjects. Asterisks indicate statistically significant differences $(\mathrm{p}<0.05)$ in transcript abundance between schizophrenia subjects and the comparison group. 


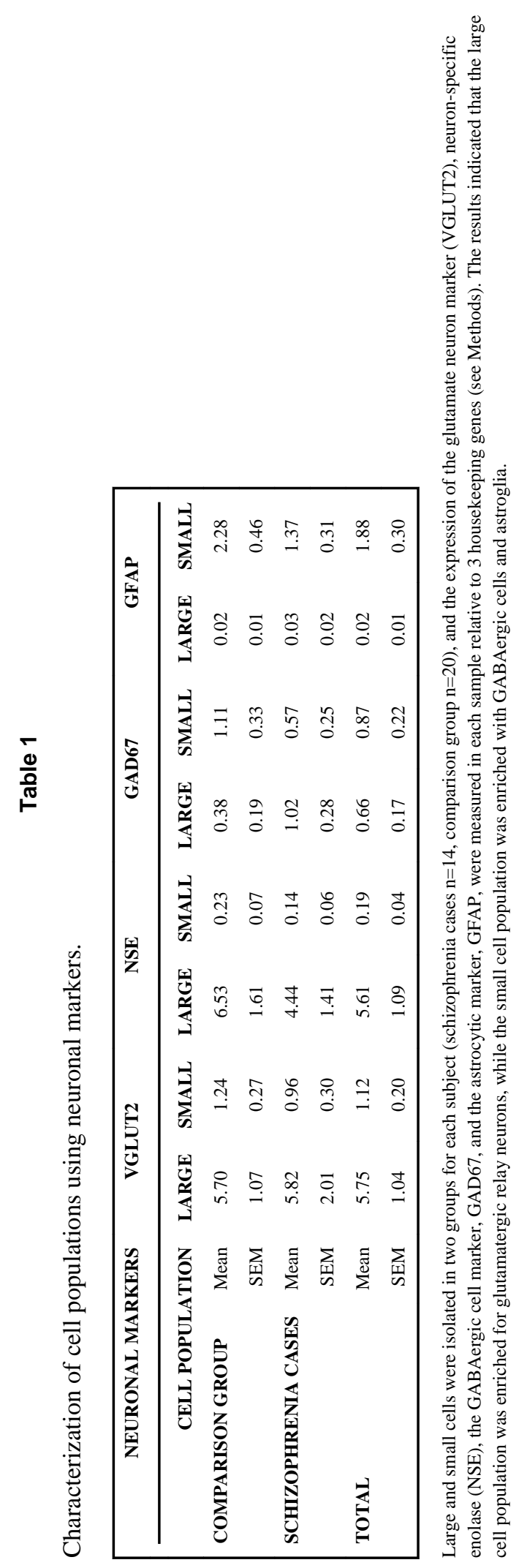

Biol Psychiatry. Author manuscript; available in PMC 2012 October 1. 


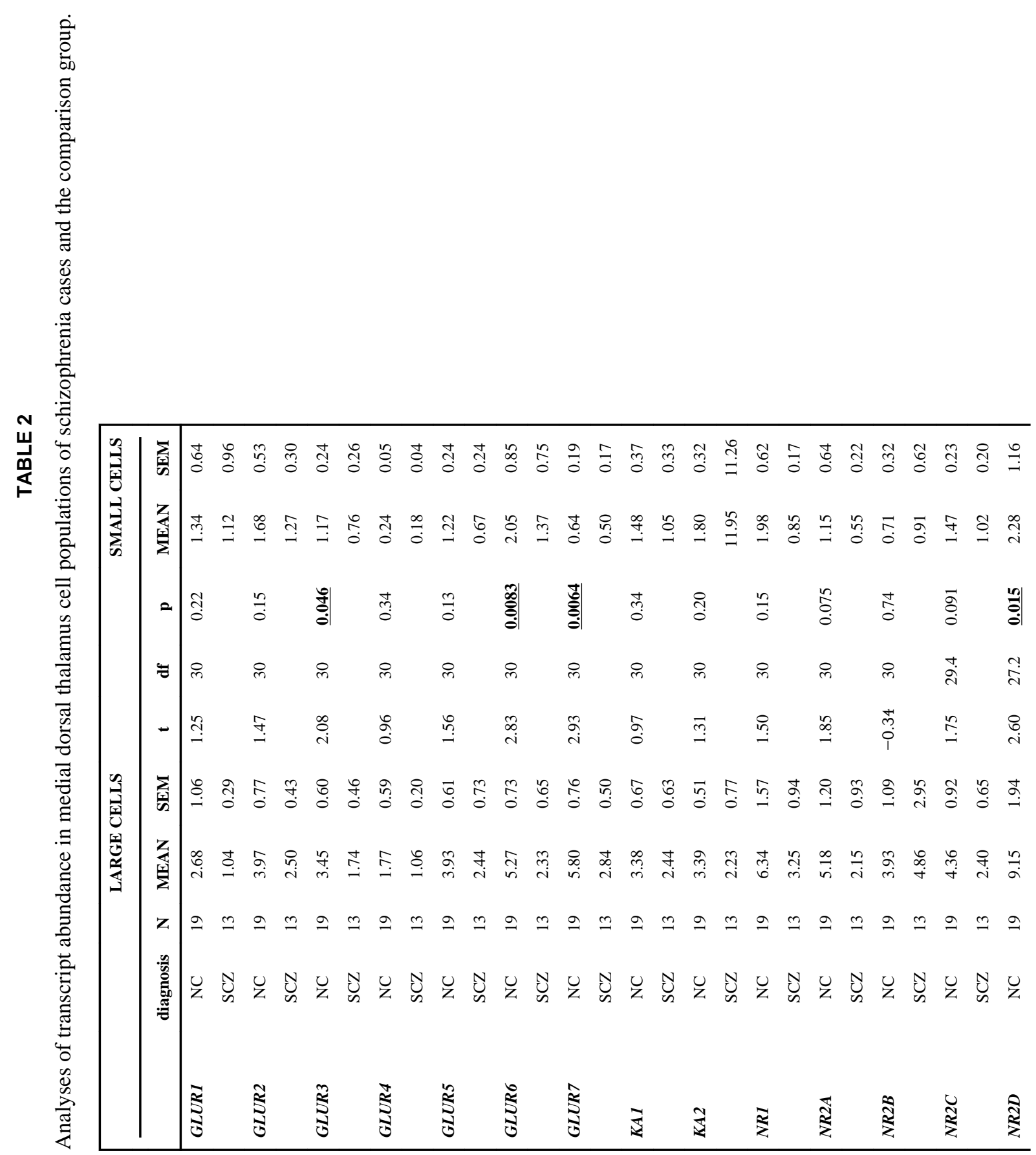

Biol Psychiatry. Author manuscript; available in PMC 2012 October 1. 


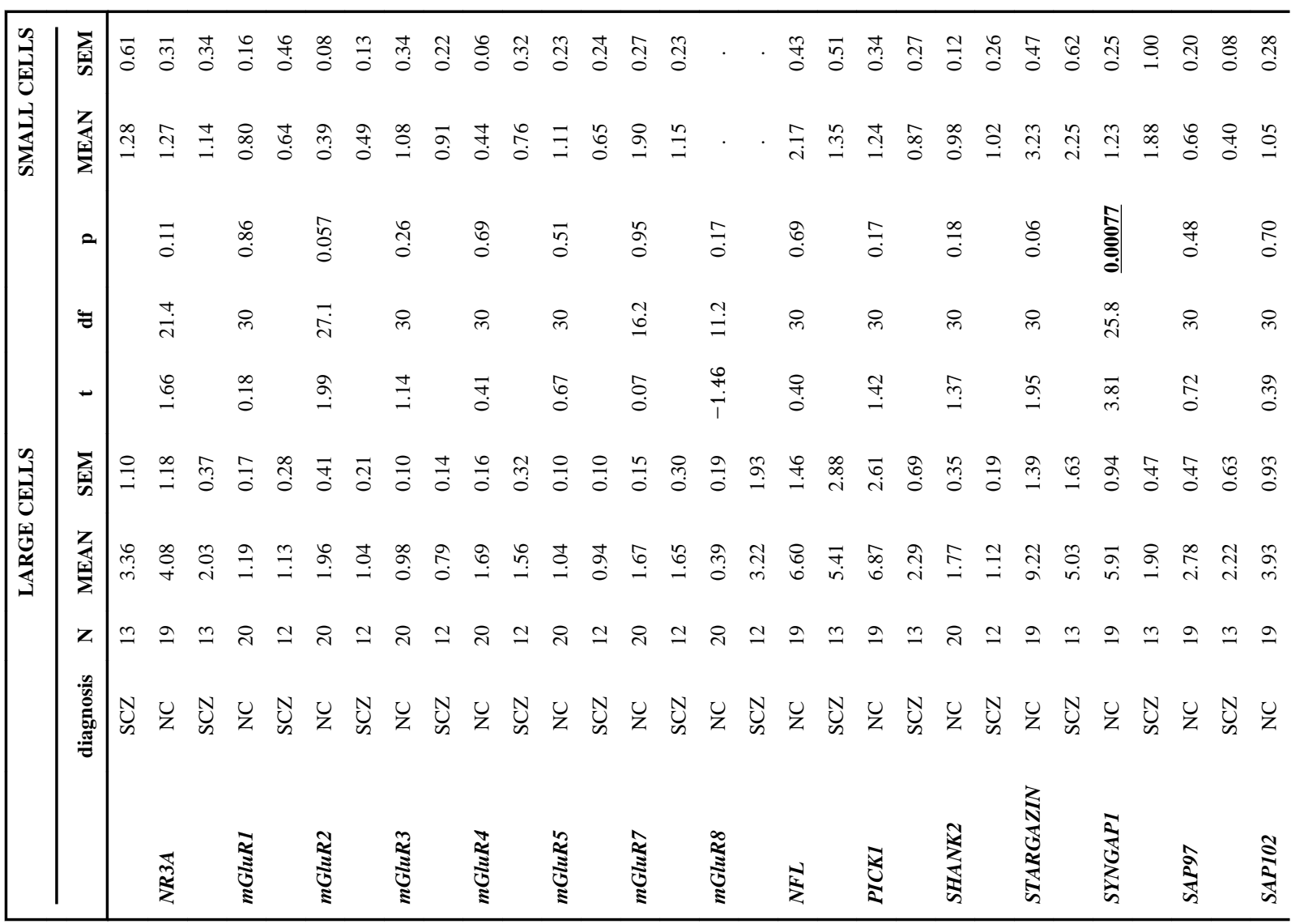




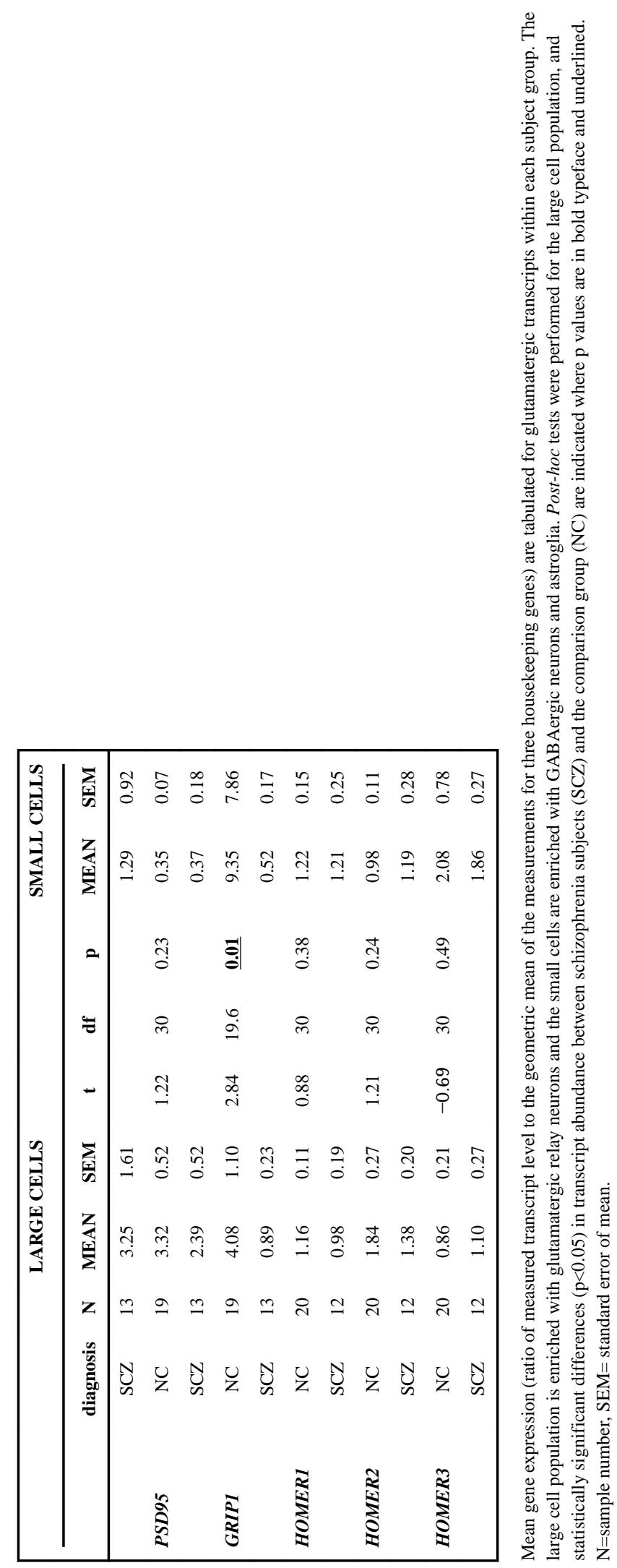

Biol Psychiatry. Author manuscript; available in PMC 2012 October 1. 